\title{
Guyanagarika, a new ectomycorrhizal genus of Agaricales from the Neotropics
}

Marisol Sánchez-García ${ }^{\mathrm{a}^{* 1}}$, Terry W. Henkel ${ }^{\mathrm{b}}$, M. Catherine Aime ${ }^{\mathrm{c}}$, Matthew E. Smith ${ }^{\mathrm{d}}$,

P. Brandon Matheny ${ }^{\mathrm{a}}$

${ }^{a}$ Department of Ecology and Evolutionary Biology, University of Tennessee, Knoxville, TN 37996, USA

${ }^{\mathrm{b}}$ Department of Biological Sciences, Humboldt State University, Arcata, CA 95521, USA

${ }^{c}$ Department of Botany \& Plant Pathology, Purdue University, West Lafayette, IN 47907, USA

${ }^{\mathrm{d}}$ Department of Plant Pathology, University of Florida, Gainesville, FL 32611, USA

* Corresponding author: Tel +1 (508) 793 7622, fax: +1 (508) 7937174.

Email: MSanchezGarcia@clarku.edu

${ }^{1}$ Present address: Biology Department, Clark University, Worcester, MA 01610, USA

\begin{abstract}
A new genus and three new species of Agaricales are described from the Pakaraima Mountains of Guyana in the central Guiana Shield. All three of these new species fruit on the ground in association with species of the ectomycorrhizal (ECM) tree genus Dicymbe (Fabaceae subfam. Caesalpinioideae) and one species has been shown to form ectomycorrhizas. Multi-locus molecular phylogenetic analyses place Guyanagarika gen. nov. within the Catathelasma clade, a lineage in the suborder Tricholomatineae of the Agaricales. We formally recognize this "Catathelasma clade" as an expanded family Catathelasmataceae that includes the genera Callistosporium, Catathelasma,
\end{abstract}


Guyanagarika, Macrocybe, Pleurocollybia, and Pseudolaccaria. Within the Catathelasmataceae, Catathelasma and Guyanagarika represent independent origins of the ectomycorrhizal habit. Guyanagarika is the first documented case of an ECM Agaricales genus known only from the Neotropics.

Keywords: Basidiomycota, Dicymbe, systematics, fungal diversity, cryptic species

\section{Introduction}

Fungi represent one of the most diverse groups of organisms with an estimated 5.1 million species, the great majority of which remain to be discovered (O'Brien et al. 2005; Blackwell 2011). In addition to their great taxonomic diversity, fungi play vital roles in nutrient cycling processes in terrestrial ecosystems through decomposition of organic matter, forming mycorrhizal symbioses, and as parasites (Leake and Read 1997).

Traditionally, fungal species have been recognized based on micro- and macromorphological characters (e.g. Singer and Smith 1943; Singer 1955; Halling 1992; Manimohan et al. 1995; Buyck et al. 2011). However, the use of morphology to establish species boundaries may often be inadequate. This is mainly because most of the phenotypic characters used to identify species are based on the sporocarps, which represent a single and short part of the fungal life cycle, and have a paucity of measurable characters relative to most other organisms (Petersen and Hughes 1999). The use of other criteria such as interbreeding potential (e.g. Ota et al. 1998; Aanen and Kuyper 1999), or phylogenetic concordance of multiple genes to indicate evolutionary independence of lineages has enabled the discovery of cryptic species within morphologically identical taxa (Harder et al. 2013; Stefani et al. 2014). The discovery of such "hidden" species- 
level diversity has facilitated the assessment of fungal diversity and conservation priorities (Hibbett and Donoghue 1996; Agapow et al. 2004).

Recent studies have suggested that ectomycorrhizal (ECM) fungal diversity is higher in temperate and boreal latitudes than in the tropics (Tedersoo et al. 2012; Tedersoo et al. 2014). Nonetheless, the importance of ECM fungi in tropical ecosystems has been highlighted, e.g. they alleviate plant stress (Bandou et al. 2006) and contribute to plant establishment and community structure (Newbery et al. 2002; Henkel et al. 2005; Peay et al. 2010). Some studies have documented high ECM fungal diversity in Paleotropical ecosystems (Peay et al. 2010; Tedersoo et al. 2010; Bâ et al. 2012). In the Neotropics, ECM fungal diversity in central Guiana Shield forests dominated by the ECM canopy tree genera Dicymbe, Pakaraimaea, and Aldina has been shown to be remarkably high (Smith et al. 2011; Henkel et al. 2012; Smith et al. 2013). In recent years, several new genera and over 100 new species have been described from this area (e.g. Henkel et al. 2011, 2016; Husbands et al. 2013; Grupe et al. 2015; Smith et al. 2015).

Among the rich assemblage of Guyana's Dicymbe-associated ECM fungi reported by Henkel et al. (2012), Smith et al. (2013) reported the discovery of a conspicuous yet enigmatic orange-colored agaric species from western Guyana. Morphologically this fungus resembles a species of Tricholoma (Fr.) Staude, with tricholomatoid stature, hyaline, smooth basidiospores, lack of a partial veil, sinuate lamella attachment, and a fruiting habit on soil in association with ECM trees. Given the paucity of reports for Tricholoma sensu lato from the Neotropics, Smith et al. (2013) attempted to place the fungus using nuclear ribosomal large subunit (LSU) sequences, but no relationship to 
Tricholoma was indicated and putative affinities with either Entoloma P. Kumm. or Clitocybe (Fr.) Staude lacked statistical support. Evidence for an ECM relationship of the fungus was obtained by matching internal transcribed spacers (ITS) sequences from Dicymbe ECM root tips with sequences obtained directly from the fungal sporocarps (Smith et al. 2013). Furthermore, large clusters of white ECM root tips are often found in the soil beneath the sporocarps of this mushroom (Smith \& Henkel, personal observations; Smith et al. 2013). The prominence of this fungus in the Dicymbeassociated ECM fungal assemblage (Henkel et al. 2012), its Tricholoma-like morphology, and initial lack of convincing molecular-based relationship with any known genus of the Agaricales motivated us to re-examine all collected specimens of this taxon and reconstruct a multi-gene phylogeny to elucidate its phylogenetic relationships and taxonomy.

\section{Materials and Methods}

\subsection{Collections and morphological analyses}

Collections were made during May-July of 1998-2002, 2008, 2010, 2012, 2013, and 2015 from the Upper Ireng, Upper Potaro, and Upper Mazaruni River Basins in the Pakaraima Mountains of Guyana in the central Guiana Shield. Collecting sites in the Upper Ireng and Upper Potaro River Basins were dominated by ECM Dicymbe corymbosa Spruce ex. Benth. and/or D. altsonii Sandw. (Henkel et al. 2012), and collecting sites in the Upper Mazaruni River Basin were dominated by ECM 
Pakaraimaea dipterocarpacea Maguire \& P.S. Ashton and D. jenmanii Sandwith (Smith et al. 2013).

Descriptions of macromorphological characters were made from fresh collections in the field. Colors were documented with the Methuen handbook of Colour (Kornerup and Wanscher 1978), with color plates noted in parentheses. Sporocarps were dried in the field with silica gel for later microscopic examination and DNA extraction. Specimens were rehydrated with $70 \%$ ethanol, sectioned by hand, and mounted in $5 \% \mathrm{KOH}$, Melzer's reagent (to test for an amyloid reaction), or stained with Congo red, Sudan IV, or cotton blue (to test for a cyanophilous reaction) following recommendations of Clémençon (2009), and examined using a Nikon Eclipse 80i microscope. Thirty basidiospores, and at least ten basidia and other structures were measured per collection. Basidiospore measurements were taken from spores deposited on the stipe. A one-way ANOVA followed by a Tukey post-hoc test were performed in R, to examine the significance of differences in spore size and shape $(\mathrm{Q}=$ quotient of length divided by width). Collections were deposited in the following herbaria: BRG, FLAS, HSC, PUL, and TENN (herbarium abbreviations per Thiers [continuously updated]). Ectomycorrhizal roots attached to hyphal cords extending from the base of some specimens were collected for future morphological and molecular studies (Smith et al. 2013). Taxonomic descriptions presented below are composite descriptions from all specimens examined.

\subsection{DNA extraction, PCR amplification, and sequencing}


The protocols of Aime and Phillips-Mora (2005), Smith et al. (2011), and Sánchez-García et al. (2014) were followed for DNA extraction, PCR amplification, and sequencing of the internal transcribed spacers (ITS), LSU, nuclear ribosomal small subunit (SSU), the largest subunit of RNA polymerase II ( $r p b 1)$, and the second largest subunit of RNA polymerase II (rpb2). The conserved domains A-C from the $r p b 1$ gene region were amplified and sequenced using the same protocols used for $r p b 2$ in SánchezGarcía et al. (2014), but with the primers gAf, fCr, int2f, int2.1f, and int2.1r (Stiller and Hall 1997; Matheny et al. 2002; Frøslev et al. 2005). GenBank accession numbers for sequences from type and other Guyana collections are shown in Table S1, along with those of other fungi used in the phylogenetic analyses.

\subsection{Sequence alignment and phylogenetic analyses}

Phylogenetic analysis of LSU sequences in Smith et al. (2013) suggested that this mushroom was closely related to Entoloma and Clitocybe, genera of the suborder Tricholomatineae. To evaluate this phylogenetic placement, we incorporated the LSU, SSU, $r p b 1$, and $r p b 2$ sequences into a dataset of the Tricholomatineae that consisted of 255 taxa including Ampulloclitocybe clavipes (Pers.) Redhead, Lutzoni, Moncalvo \& Vilgalys as an outgroup (Binder et al. 2010), hereafter referred to as the Tricholomatineae dataset. Some of these sequences were generated at the University of Tennessee, and others were obtained from GenBank. Alignments for individual gene regions were done with MAFFT 7.244 (Katoh and Standley 2013) and manually adjusted with Aliview 1.17.1 (Larsson 2014). Individual gene alignments were concatenated using SeaView 4.5.4 (Gouy et al. 2010), after inspection for intergene conflict. PartitionFinder 1.0.1 
(Lanfear et al. 2012) was used to find the best partition strategy and the best models of molecular evolution.

A maximum likelihood (ML) analysis was performed with RAxML 8.1.17

(Stamatakis 2014) executing 1000 rapid ML bootstrap searches. Bayesian inference (BI) analyses were performed using MrBayes 3.2.2 (Huelsenbeck \& Ronquist 2001; Ronquist \& Huelsenbeck 2003; Altekar \& al. 2004) with two independent runs and four Markov chain Monte Carlo (MCMC) for 50 million generations, and sampling trees every 5000 generations. To determine the appropriate number of generations to discard as burn-in, we evaluated the output using Tracer 1.5 (Rambaut and Drummond 2007), after which 25 $\%$ of the trees were discarded. Trees sampled from the posterior distribution were summarized into a maximum clade credibility (MCC) tree using TreeAnnotator 1.7.5 (Drummond \& al. 2012). Bootstrap values (BS) $\geq 70$ and posterior probabilities $\geq 0.90$ were considered evidence for strong support.

Preliminary analyses from the Tricholomatineae dataset suggested that this taxon could be closely related to the Catathelasma clade. We assembled a second dataset of sequences for the aforementioned loci that included members of the Catathelasma clade, Tricholomataceae outgroup taxa, and the orange-colored Guyana mushroom (hereafter referred as the Catathelasma clade dataset). In this dataset we also incorporated ITS sequences prior to running ML and BI analyses as described above.

\subsection{Congruence among loci}

To test the level of congruency among loci, we used the congruence among distance matrices (CADM) test (Campbell et al. 2011), as implemented in the package 
ape in $\mathrm{R}$. The null hypothesis of this test is the complete incongruence of the phylogenetic trees obtained from each locus; in other words, phylogenetic trees with different evolutionary histories. The level of congruence (W; Kendall's coefficient of concordance) ranges from 0 (total incongruence) to 1 (complete congruence).

\section{Results}

The Tricholomatineae dataset consisted of 269 specimens and 4917 nucleotide positions. The alignment was separated into nine partitions: (1) LSU; (2) SSU; (3) rpb2 first codon positions; (4) rpb2 second codon positions; (5) rpb2 third codon positions; (6) rpbl first codon positions; (7) rpbl second codon positions; (8) rpbl third codon positions; and (9) rpbl intron 2, implementing the GTR+GAMMA+I model for both the ML and BI analyses as suggested by PartitionFinder.

The Catathelasma clade dataset consisted of 50 specimens and 5921 nucleotide positions. The alignment was separated in seven partitions as suggested by PartitionFinder: (1) ITS; (2) LSU; (3) SSU; (4) rpb2 all codon positions; (5) rpb1 first and second codon positions; (6) rpbl third codon positions; and (7) rpbl intron 2, implementing the GTR+GAMMA+I model for both the ML and BI analyses as suggested by PartitionFinder.

The orange-colored mushroom complex, herein named Guyanagarika gen. nov., was recovered with high support (BS-96/PP-0.99) as sister to the Catathelasma clade (Matheny et al. 2006), a lineage that includes the genera Callistosporium Singer, Catathelasma Lovejoy, Macrocybe Pegler \& Lodge, Pleurocollybia Singer, 
Pseudolaccaria (Fr.) Vizzini, Contu \& Z.W. Ge, Clitocybe fellea, and Clitocybe aff. fellea (Fig. 1).

Based on these analyses the family Catathelasmataceae Wasser is emended to include members of the Catathelasma clade + Guyanagarika. The Catathelasmataceae was originally established in 1985 to include only one member, Catathelasma. Jülich (1981) recognized it as the family Biannulariaceae Jülich, and included the genus Biannularia Beck; however, Biannularia was later synonymized with Catathelasma (Singer 1940), keeping the latter name due to the principle of priority. Singer (1986) recognized this group as the tribe Biannularia Singer, in which he also included Armillaria (Fr.) Staude, which is now known to belong to the family Physalacriaceae (Moncalvo et al. 2002).

In the analysis of the Catathelasma dataset Guyanagarika gen. nov. was recovered as sister to Callistosporium, Clitocybe aff. fellea, Macrocybe, Pleurocollybia, and Pseudolaccaria, and three highly supported clades were recovered within Guyanagarika (Fig. 2). Results from the CADM test showed no significant incongruence among all loci, supporting three independent evolutionary lineages and the species-level recognition of the three monophyletic groups within Guyanagarika. The null hypothesis was rejected $(\mathrm{W}=0.90 ; \mathrm{p}<0.001)$. Based on the strength of the molecular analyses, we describe these clades as new species: 1) Guyanagarika aurantia sp. nov., 2) G. pakaraimensis sp. nov., and 3) G. anomala sp. nov.

The statistical analyses performed to determine differences in spore size and shape show that $G$. pakaraimensis presents significantly smaller spores (mean $=7.82 \times$ 4.95) than $G$. aurantia $($ mean $=7.96 \times 5.12)$ and $G$. anomala $($ mean $=8.01 \times 5.09)$. No 
significant differences were found across Q values. Results from the one-way ANOVA, and the post-hoc Tukey test are presented in the supplementary material (Tables S2, S3, and Fig. S1).

Phylogenetic analyses of the Catathelasma dataset (Fig. 2) show a collection of Pleurocollybia sp. as potentially congeneric with Callistosporium. These sequences were retrieved from GenBank, and we cannot confirm their taxonomic identity, although this accession may possibly represent a misidentified specimen of Callistosporium since both genera are lignicolous and morphologically similar (Table 1).

\section{Taxonomy}

Catathelasmataceae Wasser in Agarikovye griby SSSR (Kiev): 29. 1985.

Type genus: Catathelasma Lovejoy, Bot. Gaz. 50: 383. 1910.

Emended here to include the genera Callistosporium, Guyanagarika gen. nov., Macrocybe, Pleurocollybia, and Pseudolaccaria

Habit tricholomatoid, collybioid or pleurotoid. Lamellae adnate, adnexed, sinuate, emarginated to decurrent. Basidiospore deposit white. Basidiospores ellipsoid, hyaline, smooth, inamyloid or amyloid, acyanophilic or cyanophilic. Cheilocystidia present or absent, pleurocystidia absent, if present then only as pseudocystidia. Hymenophoral trama regular to bilateral becoming regular. Pileipellis a cutis, ixocutis or cutis becoming a trichoderm. Clamp connections present or absent. On soil or rotten wood. Saprotrophic or ectomycorrhizal. 
Genera included: Callistosporium, Catathelasma, Guyanagarika gen. nov., Macrocybe, Pleurocollybia, Pseudolaccaria.

Guyanagarika Sánchez-García, T.W. Henkel \& Aime, gen. nov. MycoBank MB 817738

Etymology: Guyana, in reference to the country of origin; and from the Greek agariko = agaric, or gilled mushroom.

Diagnosis: Habit tricholomatoid. Pileus dark orange becoming lighter towards the margin, broadly convex to broadly sub-conic to plano-convex with prominent broad umbo with age. Surface glabrous to minutely tomentose. Lamellae sub-thick to thick, initially adnate to adnexed, sinuate with age, brittle. Stipe equal, tapering evenly from apex to base, solid. Basidiospores hyaline, smooth, inamyloid, acyanophilic. Spore deposit white. Hymenial cystidia absent. Pileipellis initially a cutis becoming a trichoderm with age. Clamp connections present in all tissues. Thromboplerous hyphae (oleiferous hyphae sensu Clemençon 2004) present in all tissues.

Type species: Guyanagarika aurantia Sánchez-García, T.W. Henkel \& Aime, sp. nov.

Guyanagarika aurantia Sánchez-García, T.W. Henkel \& Aime, sp. nov. (Fig. 3)

MycoBank MB 817739

Etymology: from the Latin aurantia $=$ orange-colored, in reference to the uniform color of the basidioma.

Diagnosis: Morphological characteristics of the genus and similar to G. pakaraimensis and G. anomala, but forming a distinct species-level clade supported by multiple loci 
data (ITS, LSU, $r p b 1$, and $r p b 2$ ). The ITS sequence is $82-90 \%$ similar to other species of Guyanagarika, unique molecular synapomorphies at positions 31, 33, 34, 82, 109, 129, 133, 134 (ITS1); 357,359,423,466 (ITS2). The LSU sequence is 92-96\% similar to other species of Guyanagarika, unique molecular synapomorphies at positions 176, 415, 427, 436, 440, 430, 442, 443, 460, 461, 467, 489, 558, 608, 609, 616, 685, 690, 697, 778, 779. The $r p b 2$ sequence is $98-99 \%$ similar to other species of Guyanagarika, unique molecular synapomorphies at positions 7, 857, 927.

Holotype: Guyana: Region 7 Cuyuni-Mazaruni: Pakaraima Mountains, Upper Mazaruni River Basin, $\sim 6 \mathrm{~km}$ west of Mt. Ayanganna in vicinity of Pegaima savanna camp site at $5^{\circ} 26{ }^{\prime} 21.3^{\prime \prime} \mathrm{N} 60^{\circ} 04^{\prime} 43.1^{\prime \prime} \mathrm{W}, 300 \mathrm{~m}$ south of base camp, on white sand soils in forest dominated by ECM Pakaraimaea dipterocarpacea and Dicymbe jenmanii, 6 June 2012, Henkel 9693 (BRG; isotypes HSC G1184, TENN 070902). GenBank accession numbers: ITS (KX092078), LSU (KX092078), SSU (KX092111), rpb1 (KX092118), rpb2 (KX092132).

Pileus 30-60 mm broad, 15-32 $\mathrm{mm}$ tall, convex to sub-conic to plano-convex with prominent umbo 6-13 mm tall with age, orange throughout (5A8-6B3), darker orange (6B8-6C6) over disc when young, hygrophanous somewhat to lighter yellowish orange (4A6-4A7) with age, otherwise uniformly concolorous, margin incurved and subcrenulate to crenulate when young, and broadly undulate at maturity, edge sub-crenate; surface glabrous to minutely tomentose especially over disc, under hand lens a regular, low, sub-erect to erect pile of fibrillose elements more concentrated over disc, on mature 
specimens near margin erect elements reduced, nearly minutely granulose-pruinose; subdry to moist; trama off-white to pale cream (4A3-4A4), orange-concolorous under pileipellis, $0.5 \mathrm{~mm}$ at margin, $2 \mathrm{~mm}$ over lamellae, and $9 \mathrm{~mm}$ over stipe/umbo, unchanging. Lamellae sub-thick to thick, sub-distant, adnate-adnexed when young, sinuate at maturity, cream to light orange (4A5-4A6-4A7), brittle, unchanging; edges concolorous, smooth, irregularly slightly eroded in places; one to three lamellulae 1-7 (10) $\mathrm{mm}$ long. Stipe $45-105(-180) \times 6-11(-15) \mathrm{mm}$, equal to sub-equal or tapering evenly and slightly from apex to base, usually light orange (4A5-4A6), rarely creamish orange (4A3-4A4), sometimes lightening to nearly white over basal one-fifth, glabrous to finely longitudinally striate macroscopically, under hand lens with a fine, dense, and longitudinal mat with occasional minute projecting elements; trama off-white, faintly cream near stipitipellis, fibrous, solid, snapping easily and cleanly, cartilaginous; basal mycelium an off-white mat subtended by thin to thick white hyphal chords. Odor none, or fungoid when cut to slightly soapy-chemical. Taste none to slightly farinaceous.

Basidiospores 7.2-8.5 × 4.4-5.5 $\mu \mathrm{m}$ (mean $7.96 \times 5.12 \mu \mathrm{m})$, hyaline, smooth, ellipsoid, Q range $=1.4-1.8, \mathrm{Q}$ mean $=1.59$, inamyloid, acyanophilic, usually containing 2-4 guttules. Basidia 38-52 × 4.4-7 $\mu \mathrm{m}$, clavate, 4-sterigmate, occasionally 2sterigmate, hyaline. Edge of the lamellae sterile due to the presence of short, clavate, thin-walled cells resembling basidioles and rarely protruding elements. Hymenial cystidia absent. Hymenophoral trama regular to slightly interwoven. Pileipellis a cutis made up of interwoven hyphae, orange-ochraceous in mass with intracellular pigments; cells $48-80 \times 6-9 \mu \mathrm{m}$, with ascending terminal cells; subpellis consisting of interwoven hyphae. Stipitipellis a cutis; cells $61-100 \times 8-10 \mu \mathrm{m}$ with ellipsoid to cylindrical 
terminal elements. Clamp connections and thromboplerous hyphae present in all tissues.

Habit, habitat and distribution: Solitary to scattered on humic mat on sandy soils under the ECM trees Pakaraimaea dipterocarpacea and Dicymbe jenmanii in the Upper Mazaruni River Basin of Guyana; also found under Dicymbe corymbosa in the Upper Potaro and Upper Ireng River Basins of Guyana.

Other specimens examined: Guyana: Region 8 Potaro-Siparuni: Pakaraima Mountains, Upper Ireng River, Suruwubaru Creek, within $2 \mathrm{~km}$ of base camp at $5^{\circ} 05^{\prime} \mathrm{N}$ $59^{\circ} 54^{\prime} \mathrm{W}, 720 \mathrm{~m}, 1.5 \mathrm{~km}$ upstream from juncture with Yuarka River, immediate riverside, 2 March 1997, Henkel 6270 (BRG, HSC G1185, TENN 070897); 0.5 km east from riverside base camp, 27 May 1999, Henkel 7062 (BRG, HSC 1186, TENN 070898); Upper Potaro River, within $5 \mathrm{~km}$ radius of Potaro base camp at $5^{\circ} 18^{\prime} 04.8^{\prime \prime} \mathrm{N}$ 5954'40.4"W, 710 m, vicinity of base camp, 16 June 2000, Henkel 7505 (BRG, HSC G1187, TENN 070899); ibidem, 1 June 2001, Aime 1741 (BRG, PUL F3425, TENN 070895); $4 \mathrm{~km}$ southeast of base camp near mixed forest plot 3, 12 June 2001, Henkel 8269 (BRG, HSC G1188, TENN 070900); 1.5 km northeast base camp, 28 May 2010, Henkel 9235 (BRG, HSC G1189, TENN 070901), ECM sample TLW11 (FLAS F59407); 50 m northeast of base camp, 19 June 2013, Henkel 9835 (BRG, HSC G1190, TENN 070903); 300 m northeast of base camp behind Leon camp, 19 June 2013, Henkel 9836 (BRG, HSC G1191, TENN 070904); 0.5 km east of base camp between North Benny's Ridge and Leon camp, 11 June 2015, Henkel 10068 (BRG, HSC G1192, TENN 070896). 
Guyanagarika pakaraimensis Sánchez-García, T.W. Henkel \& Aime, sp. nov. (Fig. 4) MycoBank MB 817741

Etymology: pakaraimensis (-ensis Latin) indicating place of origin, referring to the locality where this species is found, the Pakaraima Mountains of Guyana.

Diagnosis: Morphological characteristics of the genus and similar to G. aurantia and $G$. anomala, but with smaller spores (mean $7.82 \times 4.95)$ and forming a distinct species-level clade supported by multiple loci data (ITS, LSU, rpb1, and rpb2). The ITS sequence is $81-90 \%$ similar to other species of Guyanagarika, unique molecular synapomorphies at positions 32, 42, 84, 108, 123, 124, 129, 132, 133 (ITS1); 360, 361, $363,460,462,464$ (ITS2). The LSU sequence is $92-96 \%$ similar to other species of Guyanagarika, unique molecular synapomorphies at possitions 181, 471, 472, 514, 558, $582,608,616,720,807$. The $r p b 2$ sequence is $98-99 \%$ similar to other species of Guyanagarika, unique molecular synapomorphies at positions 258, 830, 857.

Holotype: Guyana: Region 8 Potaro-Siparuni: Pakaraima Mountains, Upper Potaro River, within $5 \mathrm{~km}$ radius of Potaro base camp at 5¹8'04.8"N 5954'40.4"W, $710 \mathrm{~m}$, vicinity of base camp, 15 July 2008, Henkel 8941 (BRG; isotypes HSC G1193, TENN 070918). GenBank accession numbers: ITS and LSU (KT339200), SSU (KX092114), rpb1 (KX092128), rpb2 (KX092145).

Pileus (17-) 38-85 mm broad, 10-16 $\mathrm{mm}$ tall, broadly convex to plano-convex to uplifted, with a low, broad umbo 9-14 mm tall, deep orange (6A8-6B8) at center, peachorange $(5 \mathrm{~F} 4-5 \mathrm{~F} 5)$ to rich orange $(5 \mathrm{~A} 8-5 \mathrm{~B} 8)$ towards the margin; margin entire, incurved 
when young to sub-crenulate with age, sometimes crisped to eroded and irregularly split towards disc; surface initially glabrous, with age composed of fibrillose hairs upturned above disc and becoming repent towards margin, outer one-third becoming sulcate above gills with maturity, sub-moist to moist; trama $<0.5 \mathrm{~mm}$ at margin, $2 \mathrm{~mm}$ centrally, $8 \mathrm{~mm}$ above stipe, off-white, unchanging. Lamellae sub-thick to thick, sub-distant to distant, adnate-adnexed to subsinuate and slightly decurrent, pale yellow to pale orange (4A45A4), brittle, unchanging; edges concolorous, smooth to finely eroded; one to three lamellulae 1-3 mm long. Stipe (40-) 55-100 (-150) × (6-) 10-22 mm, equal, occasionally tapering from apex to base, pale orange to orangish cream (5A3-5A6) approaching apex, paler toward base, solid; surface with minute fibrillose hairs creating granulose appearance, longitudinally striate throughout; trama off-white; stipitipellis 0.5 mm thick; basal mycelium a white tomentum over lower $1 / 5$, grading downward into thin white rhizomorphs connected to concolorous ectomycorrhizae. Odor mild to faintly farinaceous. Taste mild to faintly farinaceous.

Basidiospores 6.7-8.7(-9.2) × 4.1-5.7 $\mu \mathrm{m}($ mean $7.82 \times 4.95 \mu \mathrm{m})$, hyaline, smooth, ellipsoid, Q range $=1.3-1.7, \mathrm{Q}$ mean $=1.52$, inamyloid, acyanophilic, usually with 2-4 guttules. Basidia 40-48 ×5-8 $\mu \mathrm{m}$, clavate, 4-sterigmate, occasionally 2sterigmate, hyaline. Edge of the lamellae sterile due to the presence of short, clavate, thin-walled cells resembling basidioles and rarely protruding elements. Hymenial cystidia absent. Hymenophoral trama regular to slightly interwoven. Pileipellis a cutis made up of interwoven hyphae of interwoven hyphae, orange-ochraceous in mass with intracellular pigments; cells $45-85 \times 7-8(-10) \mu \mathrm{m}$ with sub-erect, cylindrical terminal elements; subpellis consisting of interwoven hyphae. Stipitipellis a cutis; cells 39-70 × 
7-10 $\mu \mathrm{m}$, with ellipsoid to cylindrical terminal elements. Clamp connections and thromboplerous hyphae present in all tissues.

Habit, habitat and distribution: solitary to scattered on humic mat of forest floor under Dicymbe corymbosa; known from the Upper Potaro and Upper Ireng River Basins in the central Pakaraima Mountains of Guyana.

Other specimens examined: Guyana: Region 8 Potaro-Siparuni: Pakaraima Mountains, Upper Ireng River, Suruwubaru Creek, within $2 \mathrm{~km}$ of base camp at $5^{\circ} 05^{\prime} \mathrm{N}$ 5954'W, 720 m, east bank of Sukabi-Ireng confluence, 24 May 1998, Henkel 6595 (BRG, HSC G1201, TENN 070914); Mt. Kukuinang, 3 km SW from mountain peak, fringing forest on edge of savanna, 25 May 1998, Henkel 6618 (BRG, HSC G1202, TENN 070915); vicinity of base camp, 30 June 1998, Henkel 6995 (BRG, HSC G1194, TENN 070916); Upper Potaro River, within $5 \mathrm{~km}$ radius of Potaro base camp at 5¹8'04.8"N 5954'40.4"W, 710 m, Benny’s Ridge, 29 May 2012, Aime 4776 (BRG, PUL F3430, TENN 070908); across the river, vicinity of plot 3, 24 June 2000, Aime 1350 (BRG, PUL F3432, TENN 070922); across the river, vicinity of plot 3, 3 June 2012, Aime 4820 (BRG, PUL F3429, TENN 070909); within 5 km radius of Potaro base camp at $5^{\circ} 18^{\prime} 04.8^{\prime \prime} \mathrm{N} 59^{\circ} 54^{\prime} 40.4^{\prime \prime} \mathrm{W}, 710 \mathrm{~m}, 1.5 \mathrm{~km}$ southeast of base camp in Dicymbe plot 1 , 2 July 2002, Henkel 8512 (BRG, HSC G1195, TENN 070917); vicinity of base camp, 17 May 2010, Aime 3941 (BRG, PUL F3427, TENN 070905); ibidem, 27 May 2012, Aime 4749 (BRG, PUL F3431, TENN 070906); ibidem, 29 May 2012, Aime 4775 (BRG, PUL F3428, TENN 070907); 0.4 km northeast of base camp behind Leon's camp, 10 June 2015, Henkel 10051 (BRG, HSC G1196, TENN 070911); 0.5 km northeast of base camp on line to old Ayanganna airstrip, 18 June 2015, Henkel 10108 (BRG, HSC G1197, 
TENN 070921); 0.5 km northeast of base camp on line to old Ayanganna airstrip, Henkel 10114 (BRG, HSC G1198, TENN 070912); 1 km northeast of base camp in vicinity of old Ayanganna airstrip, Henkel 10123 (BRG, HSC G1199, TENN 070913).

Guyanagarika anomala Sánchez-García, T.W. Henkel \& Aime, sp. nov.

(Fig. 5)

MycoBank MB 817742

Etymology: from the Latin anomala $=$ abnormal, anomalous

Diagnosis: Morphological characteristics of the genus and similar to G. aurantia and G. pakaraimensis, but forming a distinct species-level clade supported by multiple loci data (ITS, LSU, and $r p b 2$ ). The ITS sequence is $81-82 \%$ similar to other species of Guyanagarika, unique molecular synapomorphies at positions 41, 43, 50, 66, 81, 100, 102, 104, 126, 129, 131, 133, 137, 142, 146 (ITS1); 308, 319, 328, 331, 332, 341, 347, $348,376,381,385,454,455,456,461,463$ (ITS2). The LSU sequence is $92 \%$ similar to other species of Guyanagarika, unique molecular synapomorphies at positions 134, 143, $177,214,215,224,240,448,464,485,498,499,558,561,565,576,590,591,594,596$, $600,607,608,610,613,616,619,686,714,730,763,806,816$; The $r p b 2$ sequence is 81-82\% similar to other species of Guyanagarika, unique molecular synapomorphies at positions $3,8,36,42,57,60,123,174,180,192,213,297,426,498,649,685,686,702$, $762,813,846,857,879,912$.

Holotype: Guyana: Region 8 Potaro-Siparuni: Pakaraima Mountains, Upper Potaro River, within $5 \mathrm{~km}$ radius of Potaro base camp at $5^{\circ} 18^{\prime} 04.8^{\prime \prime N} 59^{\circ} 54^{\prime} 40.4^{\prime \prime} \mathrm{W}, 710 \mathrm{~m}$, 
vicinity of base camp, 26 May 2000, Henkel 7419 (BRG; isotypes HSC G1200, TENN 070920). GenBank accession numbers: ITS (KX092096), LSU (KX092110), rpb2 (KX092147).

Pileus 40-130 mm broad, convex to plane to slightly uplifted, deep orange (5A85B8-5C8) at disc, paler (4A5) towards margin; margin broadly scalloped and wavy; surface glabrous to coarsely rugose, whitish canescent over disc, trama off-white. Lamellae sub-thick to thick, close to sub-distant, adnate to adnexed, pale yellow-orange (4A4), brittle, edges coarsely and irregularly serrate with age, up to 6 lamellulae. Stipe $35-140 \times 9-25 \mathrm{~mm}$, equal or tapering towards the base, pale yellow orange (4A2-4A3), mostly glabrous, longitudinally striate; trama off-white, fibrous; basal mycelium a fine white tomentum. Odor none. Taste mild.

Basidiospores 7-9(-9.5) × 4.1-5.5 $\mu \mathrm{m}($ mean $8.01 \times 5.09 \mu \mathrm{m})$, hyaline, smooth, ellipsoid, $\mathrm{Q}$ range $=1.4-1.8, \mathrm{Q}$ mean $=1.63$, inamyloid, acyanophilic, usually with $2-4$ guttules. Basidia 48-55 × 5-8.8 $\mu \mathrm{m}$, clavate, 4-sterigmate, occasionally 2-sterigmate, hyaline. Edge of the lamellae sterile due to the presence of short, clavate, thin-walled cells resembling basidioles and rarely protruding elements. Hymenial cystidia absent. Hymenophoral trama regular to slightly interwoven. Pileipellis a cutis made up of interwoven hyphae, orange-ochraceous in mass with intracellular pigments; cells 55-90 $\times$ 6-10 $\mu \mathrm{m}$, with sub-erect, cylindrical terminal elements; sub-pellis consisting of interwoven hyphae. Stipitipellis a cutis; cells $48-89 \times 7-10 \mu \mathrm{m}$, with ellipsoid to cylindrical terminal elements. Clamp connections and thromboplerous hyphae present in all tissues. 
Habit, habitat and distribution: solitary on humic mat of forest floor under Dicymbe corymbosa, known from the Upper Potaro River Basin of Guyana.

Other specimens examined: Guyana: Region 8 Potaro-Siparuni: Pakaraima Mountains, Upper Potaro River, within $5 \mathrm{~km}$ radius of Potaro base camp at $5^{\circ} 18^{\prime} 04.8^{\prime \prime} \mathrm{N}$ 5954'40.4"W, 710 m, vicinity of base camp, 18 May 2001, Aime 1519 (BRG, PUL F3426, TENN 070919).

\section{Discussion}

Guyanagarika is recognized in the field by its medium to large basidiomata that are uniformly bright orange in color, prominently umbonate pileus, relatively thick, sinuate lamellae, lack of a partial veil, and always fruits directly on soil in association with ECM trees. This tricholomatoid stature combined with hyaline, smooth, inamyloid basidiospores of Guyanagarika immediately bring to mind the largely north temperate ECM agaricoid genus Tricholoma (Bigelow 1979; Riva 2003). Based solely on morphology Guyanagarika would be best placed in Tricholoma. Molecular data, however, do not support this relationship. The tricholomatoid stature combined with the thick lamellae gives some resemblance to the genus Hygrophorus, but Guyanagarika lacks the divergent hymenophoral trama characteristic of that genus.

In addition to the new genus, we recognize the three distinct, highly resolved lineages within Guyanagarika as different species. While statistical differences were found in the average spore length and width of G. pakaraimensis with respect to the other two species, these differences are very small $(<0.2 \mu \mathrm{m})$, and not very informative to help 
distinguish G. pakaraimensis from G. aurantia and G. anomala. It is widely accepted that some fungal species are difficult to distinguish from each other based on morphology alone, and such cryptic diversity may be rather common (e.g. Geml et al. 2006; Hallenberg et al. 2007; Hughes et al. 2007; Sato et al. 2007; Hasegawa et al. 2010; Jargeat et al. 2010; Gazis et al. 2011; Harder et al. 2013; Stefani et al. 2014; SánchezRamírez et al. 2015; Singh et al. 2015). It has also been shown that the application of species recognition criteria can affect not just diversity estimates, but also ecological and evolutionary hypotheses, and conservation strategies (Agapow et al. 2004; Frankham et al. 2012). The recognition of G. aurantia, G. pakaraimensis, and G. anomala is only possible through molecular markers. Of special note is that these three cryptic species occur sympatrically in the same local ecosystem.

The presence of other cryptic species in this geographical area has been previously documented within Clavulina sprucei and Singerocomus rubriflavus (Henkel et al. 2011; Henkel et al. 2016). Henkel et al. (2016) found that the possible cryptic species of S. rubriflavus associate with different host plants in sites $\sim 100 \mathrm{~km}$ distant, perhaps driving speciation within this bolete group. We do not see this occurring within the three species of Guyanagarika, as they are sympatric and have overlapping hosts. Initially, the Catathelasmataceae consisted of only one genus, Catathelasma. Singer (1986) included this genus in his broad concept of the Tricholomataceae, and the two families were synonymized. Moncalvo et al. (2002) and Matheny et al. (2006) recognized the Catathelasma clade as one of the major groupings within the Tricholomatoid clade (suborder Tricholomatineae). At that time only three genera were recognized as part of this clade, Callistosporium, Catathelasma, and Clitocybe subvelosa, 
the latter being subsequently transferred to the genus Cleistocybe Ammirati, A.D. Parker \& Matheny (Ammirati et al. 2007). Our analyses failed to recover the latter species as part of the Catathelasma clade, but recovered the genera Callistosporium, Catathelasma, Pleurocollybia, Pseudolaccaria, Macrocybe, and Clitocybe aff. fellea. While there are no obvious morphological or ecological synapomorphies uniting members of the Catathelasmataceae (Table 1), in previous studies these taxa have consistently formed a monophyletic group within the suborder Tricholomatineae (Matheny et al. 2006; Ammirati et al. 2007; Sánchez-García et al. 2014). Guyanagarika is strongly supported as sister taxon to these taxa within the expanded Catathelasmataceae (Fig. 1).

The relationship between Cleistocybe and Catathelasma has been examined in detail by Ammirati et al. (2007); both genera are characterized by having a partial veil, divergent hymenophoral trama, and acyanophilic spores. Based on these morphological similarities, and the fact that the phylogenetic position of Cleistocybe within the Tricholomatineae is not well supported (Fig. 1), we consider that this taxon may certainly be part of the Catathelasmataceae, and that failure to recover Cleistocybe as part of this family could be due to missing data (the lack of $r p b 1$ and $r p b 2$ sequences) in our phylogenetic analyses. These two loci have been shown to increase resolution and have higher proportions of informative characters than ribosomal DNA sequences (Matheny et al. 2002; Frøslev et al. 2005; Schoch et al. 2009); however, to date only ribosomal sequences are available for Cleistocybe. Additionally, based on our phylogenetic analyses Clitocybe fellea appears congeneric with Pseudolaccaria, although future work is needed to determine whether it is conspecific or a distinct species of Pseudolaccaria, as has been previously discussed by Lavorato et al. (2015). 
Guyanagarika represents an independent evolutionary origin of the ECM lifestyle within the Catathelasmataceae, and within the Agaricales in general. While some putatively endemic ECM lineages have been detected from ECM root sequences from various tropical sites (Tedersoo and Smith 2013) and some unique ECM Neotropical genera in the Boletaceae have recently been described (Smith et al. 2015; Henkel et al. 2016), Guyanagarika represents the only known ECM genus among the Agaricales with a distribution restricted to the Neotropics, and more specifically to Guyana, based on current knowledge and sampling. As only a small fraction of the estimated fungal diversity is currently known (Blackwell 2011), the knowledge of the distribution of this genus may be expanded as new areas and more fungal taxa are studied.

\section{Acknowledgements}

This work was supported by a graduate research award from the department of Ecology and Evolutionary Biology at the University of Tennessee to MSG; National Science Foundation (NSF) DEB-0918591, DEB-1556412, and the National Geographic Society's Committee for Research and Exploration grants 6679-99, 7435-03 and 8481-08 to TWH; the Linnean Society of London, the Explorer's Club, and (NSF) DEB-1051782 to MCA; and (NSF) DEB-1354802 to MES. Dillon Husbands functioned as Guyanese local counterpart and assisted with field collecting, descriptions and specimen processing. Additional field assistance in Guyana was provided by M. Chin, P. Henkel, C. Andrew, V. Joseph, P. Joseph, F. Edmund and L. Edmund. We thank Rachel Swenie for her assistance with the line drawings, and the UT Genomics Core for providing sequencing services. This paper is No. 223 in the Smithsonian Institution's Biological Diversity of 
the Guiana Shield Program publication series.

\section{References}

Aanen DK, Kuyper TW, 1999. Intercompatibility tests in the Hebeloma crustuliniforme complex in Northwestern Europe. Mycologia 91: 783-795.

Agapow P-M, Bininda-Emonds ORP, Crandall KA, Gittleman JL, Mace GM, Marshall JC, Purvis A, 2004. The impact of species concept on biodiversity studies. The Quarterly Review of Biology 79: 161-179.

Aime MC, Phillips-Mora W, 2005. The causal agents of witches' broom and frosty pod rot of cacao (chocolate, Theobroma cacao) form a new lineage of Marasmiaceae. Mycologia 97: 1012-1022.

Altekar G, Dwarkadas S, Huelsenbeck JP, Ronquist F, 2004. Parallel Metropolis-coupled Markov chain Monte Carlo for Bayesian phylogenetic inference. Bioinformatics 20: $407-415$.

Ammirati JF, Parker AD, Matheny PB, 2007. Cleistocybe, a new genus of Agaricales. Mycoscience 48: 282-289.

Bâ AM, Duponnois R, Moyersoen B, Diédhiou AG, 2012. Ectomycorrhizal symbiosis of tropical African trees. Mycorrhiza 22: 1-29.

Bandou E, Lebailly F, Muller F, Dulormne M, Toribio A, Chabrol J, Courtecuisse R, Plenchette C, Prin Y, Duponnois R, Thiao M, Sylla S, Dreyfus B, Bâ AM, 2006. The ectomycorrhizal fungus Scleroderma bermudense alleviates salt stress in seagrape (Coccoloba uvifera L.) seedlings. Mycorrhiza 16: 559-565.

Bigelow HE, 1979. A contribution to Tricholoma. Beihefte zur Sydowia. Annales 
Mycologici Series II 8: 54-62.

Binder M, Larsson K-H, Matheny PB, Hibbett DS, 2010. Amylocorticiales ord. nov. and Jaapiales ord. nov.: Early diverging clades of Agaricomycetidae dominated by corticioid forms. Mycologia 102: 865-880.

Blackwell M, 2011. The fungi: 1, 2, 3 ... 5.1 million species? American Journal of Botany 98: $426-438$.

Buyck B, Academy S, Naturelle H, Buffon R, 2011. The species of Russula subsection Xerampelinae described by C. H. Peck and Miss G. S. Burlingham. Cryptogamie, Mycologie 32: 63-81.

Campbell V, Legendre P, Lapointe F-J, 2011. The performance of the congruence among distance matrices (CADM) test in phylogenetic analysis. BMC Evolutionary Biology 11: 64 .

Clémençon H, 2004. Cytology and Plectology of the Hymenomycetes. Bibliotheca Mycologica 199: 1-488.

Clémençon H, 2009. Methods for working with macrofungi. Laboratory cultivation and preparation of larger fungi for light microscopy. IHM Verlag, Eching, Germany.

Drummond AJ, Suchard MA, Xie D, Rambaut A, 2012. Bayesian phylogenetics with BEAUti and the BEAST 1.7. Molecular Biology and Evolution 29: 1969-1973.

Frankham R, Ballou JD, Dudash MR, Eldridge MDB, Fenster CB, Lacy RC, Mendelson III JR, Porton IJ, Ralls K, Ryder OA, 2012. Implications of different species concepts for conserving biodiversity. Biological Conservation 153: 25-31.

Frøslev TG, Matheny PB, Hibbett DS, 2005. Lower level relationships in the mushroom genus Cortinarius (Basidiomycota, Agaricales): A comparison of RPB1, RPB2, and 
ITS phylogenies. Molecular Phylogenetics Evolution 37: 602-618.

Gazis R, Rehner S, Chaverri P, 2011. Species delimitation in fungal endophyte diversity studies and its implications in ecological and biogeographic inferences. Molecular Ecology 20: 3001-3013.

Geml J, Laursen GA, O’Neill K, Nusbaum HC, Taylor DL, 2006. Beringian origins and cryptic speciation events in the fly agaric (Amanita muscaria). Molecular Ecology 15: $225-239$.

Gouy M, Guindon S, Gascuel O, 2010. SeaView version 4: A multiplatform graphical user interface for sequence alignment and phylogenetic tree building. Molecular Biology Evolution 27: 221-224.

Grupe AC, Baker AD, Uehling JK, Smith ME, Baroni TJ, Lodge DJ, Henkel TW, 2015. Sarcodon in the Neotropics I: new species from Guyana, Puerto Rico and Belize. Mycologia 107: 591-606.

Hallenberg N, Nilsson RH, Antonelli A, Wu SH, Maekawa N, Nordén B, 2007. The Peniophorella praetermissa species complex (Basidiomycota). Mycological Research 111: 1366-1376.

Halling RE, 1992. A new species of Boletus section Luridi from Colombia. Brittonia 44: $322-325$.

Harder CB, Læssøe T, Frøslev TG, Ekelund F, Rosendahl S, Kjøller R, 2013. A threegene phylogeny of the Mycena pura complex reveals 11 phylogenetic species and shows ITS to be unreliable for species identification. Fungal Biology 117: 764-775.

Hasegawa E, Ota Y, Hattori T, Kikuchi T, 2010. Sequence-based identification of Japanese Armillaria species using the elongation factor-1 alpha gene. Mycologia 
102: $898-910$.

Henkel TW, Aime C, Uehling JK, Smith ME, 2011. New species and distribution records of Clavulina (Cantharellales, Basidiomycota) from the Guiana Shield. Mycologia 103: 883-894.

Henkel TW, Aime MC, Chin MML, Miller SL, Vilgalys R, Smith ME, 2012. Ectomycorrhizal fungal sporocarp diversity and discovery of new taxa in Dicymbe monodominant forests of the Guiana Shield. Biodiversity and Conservation 21: $2195-2220$.

Henkel TW, Mayor JR, Woolley LP, 2005. Mast fruiting and seedling survival of the ectomycorrhizal, monodominant Dicymbe corymbosa (Caesalpiniaceae) in Guyana. New Phytologist 167: 543-556.

Henkel TW, Obase K, Husbands D, Uehling JK, Bonito G, Aime MC, Smith ME, 2016. New Boletaceae taxa from Guyana: Binderoboletus segoi gen. and sp. nov., Guyanaporus albipodus gen. and sp. nov., Singerocomus rubriflavus gen. and sp. nov., and a new combination for Xerocomus inundabilis. Mycologia 108: 157-173. Hibbett DS, Donoghue MJ, 1996. Implications of phylogenetic studies for conservation of genetic diversity in shiitake mushrooms. Conservation Biology 10: 1321-1327.

Huelsenbeck JP, Ronquist F, 2001. MRBAYES: Bayesian inference of phylogenetic trees. Bioinformatics 17: 754-755.

Hughes KW, Petersen RH, Mata JL, Psurtseva N, Kovalenko A, Morosova O, Lickey E, Cifuentes-Blanco J, Lewis D, Nagasawa E, Halling RE, Takehashi S, Aime MC, Bau T, Henkel T, 2007. Megacollybia (Agaricales). Report of the Tottori Mycologial Institute 45: 1-57. 
Husbands DR, Henkel TW, Bonito G, Vilgalys R, Smith ME, 2013. New species of Xerocomus (Boletales) from the Guiana Shield, with notes on their mycorrhizal status and fruiting occurrence. Mycologia 105: 422-435.

Jargeat P, Martos F, Carriconde F, Gryta H, Moreau PA, Gardes M, 2010. Phylogenetic species delimitation in ectomycorrhizal fungi and implications for barcoding: The case of the Tricholoma scalpturatum complex (Basidiomycota). Molecular Ecology 19: $5216-5230$.

Jülich W, 1981. Higher taxa of Basidiomycetes. Bibiotheca Mycologica 85: 1-485.

Katoh K, Standley DM, 2013. MAFFT multiple sequence alignment software version 7: Improvements in performance and usability. Molecular Biology and Evolution 30: $772-780$.

Kornerup A, Wanscher JH, 1978. Methuen handbook of colour, 3rd edn. Methuen \& Co., London.

Lanfear R, Calcott B, Ho SYW, Guindon S, 2012. Partitionfinder: combined selection of partitioning schemes and substitution models for phylogenetic analyses. Molecular Biology and Evolution 29: 1695-1701.

Larsson A, 2014. AliView: a fast and lightweight alignment viewer and editor for large data sets. Bioinformatics 22: 3276-3278.

Lavorato C, Vizzini A, Ge Z, Contu M, 2015. Redescription of Clitocybe umbrinopurpurascens (Basidiomycota, Agaricales) and revision of Neohygrophorus and Pseudoomphalina. Phytotaxa 219: 43-57.

Leake JR, Read DJ, 1997. Mycorrhizal fungi in terrestrial habitats. In: Wicklow DT, Södeström B (eds), The Mycota IV. Environmental and Microbial Relationships. 
Springer, Berlin, Germany, pp. 281-301.

Manimohan P, Joseph AV, Leelavathy KM, 1995. The genus Entoloma in Kerala State, India. Mycological Research 99: 1083-1097.

Matheny PB, Curtis JM, Hofstetter V, Aime MC, Moncalvo JM, Ge ZW, Slot JC, Ammirati JF, Baroni TJ, Bougher NL, Hughes KW, Lodge DJ, Kerrigan RW, Seidl MT, Aanen DK, DeNitis M, Daniele GM, Desjardin DE, Kropp BR, Norvell LL, Parker A, Vellinga EC, Vilgalys R, Hibbett DS, 2006. Major clades of Agaricales: a multilocus phylogenetic overview. Mycologia 98: 982-995.

Matheny PB, Liu YJ, Ammirati JF, Hall B, 2002. Using rpb1 sequences to improve phylogenetic inference among mushrooms. American Journal of Botany 89: 688698.

Moncalvo JM, Vilgalys R, Redhead SA, Johnson JE, James TY, Catherine Aime M, Hofstetter V, Verduin SJ, Larsson E, Baroni TJ, Greg Thorn R, Jacobsson S, Clémençon H, Miller OK Jr., 2002. One hundred and seventeen clades of euagarics. Molecular Phylogenetics Evolution 23: 357-400.

Newbery DM, Chuyong GB, Green JJ, Songwe NC, Tchuenteu F, Zimmermann L, 2002. Does low phosphorus supply limit seedling establishment and tree growth in groves of ectomycorrhizal trees in a central African rainforest? New Phytologist 156: 297 311.

O’Brien HE, Parrent JL, Jackson JA, Moncalvo JM, 2005. Fungal community analysis by large-scale sequencing of environmental samples fungal community analysis by large-scale sequencing of environmental samples. Applied and Environmental Microbiology 71: 5544-5550. 
Ota Y, Matsushita N, Nagasawa E, Terashita T, Fukuda K, Suzuki D, 1998. Biological species of Armillaria in Japan. Plant Disease 82: 537-543.

Peay KG, Kennedy PG, Davies SJ, Tan S, Bruns TD, 2010. Potential link between plant and fungal distributions in a dipterocarp rainforest: community and phylogenetic structure of tropical ectomycorrhizal fungi across a plant and soil ecotone. New Phytologist 185: 529-542.

Petersen RH, Hughes KW, 1999. Species and speciation in mushrooms: Development of a species concept poses difficulties. Bioscience 49: 440-452.

Rambaut A, Drummond AJ, 2007. Tracer version 1.4.

Riva A, 2003. Tricholoma (Fr.) Staude Fungi Europeai 3. Edizioni Candusso, Italy.

Ronquist F, Huelsenbeck JP, 2003. MrBayes 3: Bayesian phylogenetic inference under mixed models. Bioinformatics 19: 1572-1574.

Sánchez-García M, Matheny PB, Palfner G, Lodge DJ, 2014. Deconstructing the Tricholomataceae (Agaricales) and introduction of the new genera Albomagister, Corneriella, Pogonoloma and Pseudotricholoma. Taxon 63: 993-1007.

Sánchez-Ramírez S, Tulloss RE, Guzmán-Dávalos L, Cifuentes-Blanco J, Valenzuela R, Estrada-Torres A, Ruán-Soto F, Díaz-Moreno R, Hernández-Rico N, Torres-Gómez M, León H, Moncalvo JM, 2015. In and out of refugia: Historical patterns of diversity and demography in the North American Caesar's mushroom species complex. Molecular Ecology 24: 5938-5956.

Sato H, Yumoto T, Murakami N, 2007. Cryptic species and host specificity in the ectomycorrhizal genus Strobilomyces (Strobilomycetaceae). American Journal of Botany 94: 1630-1641. 
Schoch CL, Sung GH, López-Giráldez F, Townsend JP, Miadlikowska J, Hofstetter V, Robbertse B, Matheny PB, Kauff F, Wang Z, Gueidan C, Andrie RM, Trippe K, Ciufetti LM, Wynns A, Fraker E, Hodkinson BP, Bonito G, Groenewald JZ, Arzanlou M, de Hoog GS, Crous PW, Hewitt D, Pfister DH, Peterson K, Gryzenhout M, Wingfield MJ, Aptroot A, Suh SO, Blackwell M, Hillis DM, Griffith GW, Castlebury LA, Rossman AY, Lumbsch HT, Lücking R, Büdel B, Rauhut A, Diederich P, Ertz D, Geiser DM, Hosaka K, Inderbitzin P, Kohlmeyer J, VolkmannKohlmeyer B, Mostert L, O'Donnell K, Sipman H, Rogers JD, Shoemaker RA, Sugiyama J, Summerbell RC, Untereiner W, Johnston PR, Stenroos S, Zuccaro A, Dyer PS, Crittenden PD, Cole MS, Hansen K, Trappe JM, Yahr R, Lutzoni F, Spatafora JW, 2009. The Ascomycota tree of life: a phylum-wide phylogeny clarifies the origin and evolution of fundamental reproductive and ecological traits. Systematic Biology 58: 224-39.

Singer R, 1940. Notes sur quelques Basidiomycètes. Revue de Mycologie 5: 3-13.

Singer R, 1955. New species of Agaricales from Pernambuco. Anais da Sociedade de Biologia de Pernambuco 13: 225-233.

Singer R, 1986. The Agaricales in modern Taxonomy, 4th edn. Koeltz Scientific Books, Koenigstein.

Singer R, Smith AH, 1943. A monograph on the genus Leucopaxillus Boursier. Papers of the Michigan Academy of Science 28: 85-132.

Singh G, Grande FD, Divakar PK, Otte J, 2015. Coalescent-based species delimitation approach uncovers high cryptic diversity in the cosmopolitan lichen-forming fungal genus Protoparmelia (Lecanorales, Ascomycota). PLoS One 1-20. 
Smith ME, Amses KR, Elliot T, Obase, K, Aime, MC, Henkel TW, 2015. New sequestrate fungi from Guyana: Jimtrappea guyanensis gen. sp. nov., Castellanea pakaraimophila gen. sp. nov., and Costatisporus cyanescens gen. sp. nov. (Boletaceae, Boletales). IMA Fungus 6: 297-317.

Smith ME, Henkel TW, Catherine Aime M, Fremier AK, Vilgalys R, 2011. Ectomycorrhizal fungal diversity and community structure on three co-occurring leguminous canopy tree species in a Neotropical rainforest. New Phytologist 192: 699-712.

Smith ME, Henkel TW, Uehling JK, Fremier Ak, Clarke HD, Vilgalys R, 2013. The ectomycorrhizal fungal community in a neotropical forest dominated by the endemic dipterocarp Pakaraimaea dipterocarpacea. PLoS One 8: e55160.

Stamatakis A, 2014. RAxML version 8: a tool for phylogenetic analysis and post-analysis of large phylogenies. Bioinformatics 30: 1312-1313.

Stefani FOP, Jones RH, May TW, 2014. Concordance of seven gene genealogies compared to phenotypic data reveals multiple cryptic species in Australian dermocyboid Cortinarius (Agaricales). Molecular Phylogenetics and Evolution 71: $249-260$.

Stiller JW, Hall BD, 1997. The origin of red algae: implications for plastid evolution. Proccedings of the National Academy of Sciences 94: 4520-4525.

Tedersoo L, Bahram M, Põlme S, Kõljalg U, Yorou NS, Wijesundera R, Villarreal Ruiz L, Vasco-Palacios AM, Thu PQ, Suija A, Smith ME, Sharp C, Saluveer E, Saitta A, Rosas M, Riit T, Ratkowsky D, Pritsch K, Põldmaa K, Piepenbring M, Phosri C, Peterson M, Parts K, Pärtel K, Otsing E, Nouhra E, Njouonkou AL, Nilsson RH, 
Morgado LN, Mayor J, May TW, Majuakim L, Lodge DJ, Lee SS, Larsson KH, Kohout P, Hosaka K, Hiiesalu I, Henkel TW, Harend H, Guo LD, Greslebin A, Grelet G, Geml J, Gates G, Dunstan W, Dunk C, Drenkhan R, Dearnaley J, De Kesel A, Dang T, Chen X, Buegger F, Brearley FQ, Bonito G, Anslan S, Abell S, Abarenkov K, 2014. Global diversity and geography of soil fungi. Science 346: $1078-1088$.

Tedersoo L, Bahram M, Toots M, Diédhiou AG, Henkel TW, Kjøller R, Morris MH, Nara K, Nouhra E, Peay KG, Põlme S, Ryberg M, Smith ME, Kõljalg U, 2012. Towards global patterns in the diversity and community structure of ectomycorrhizal fungi. Molecular Ecology 21: 4160-4170.

Tedersoo L, Nilsson RH, Abarenkov K, Jairus T, Sadam A, Saar I, Bahram M, Bechem E, Chuyong G, Kõljalg U, 2010. 454 Pyrosequencing and Sanger sequencing of tropical mycorrhizal fungi provide similar results but reveal substantial methodological biases. New Phytologist 188: 291-301.

Tedersoo L, Smith ME, 2013. Lineages of ectomycorrhizal fungi revisited: Foraging strategies and novel lineages revealed by sequences from belowground. Fungal Biology Reviews 27: 83-99.

Thiers B, [continuously updated] Index herbariorum: a global directory of public herbaria and associated staff. New York Botanical Garden's virtual herbarium. http://sweetgum.nybg.org/ih/.

\section{FIGURE CAPTIONS}

Figure 1. Maximum likelihood phylogeny (LSU, SSU, rpb1, rpb2) of the suborder 
Tricholomatineae. Bootstrap values $\geq 70$ are shown above branches and Bayesian posterior probabilities $\geq 0.90$ are shown below branches.

Figure 2. Maximum likelihood phylogeny (LSU, SSU, $r p b 1, r p b 2$, ITS) of the family Catathelasmataceae. Bootstrap values $\geq 70$ are shown above branches and Bayesian posterior probabilities $\geq 0.90$ are shown below branches.

Figure 3. Guyanagarika aurantia A. Basidiomata (holotype TH9693). Bar $=10 \mathrm{~mm}$. B. Basidioma ventral view. C. Basidiospores. D. Terminal cells of the pileipellis. E. Basidia. F. Terminal cells of the stipitipellis. Bar $=10 \mu \mathrm{m}$

Figure 4. Guyanagarika pakaraimensis A. Basidiomata (holotype TH8941). Bar $=10$ mm. B. Basidia. C. Basidiospores. D. Terminal cells of the stipitipellis. E. Terminal cells of the pileipellis. $\mathrm{Bar}=10 \mu \mathrm{m}$

Figure 5. Guyanagarika anomala A. Basidiomata (holotype TH7419). Bar $=10 \mathrm{~mm}$. B. Basidiospores. C. Basidia. D. Terminal cells of the pileipellis. E. Terminal cells of the stipitipellis. Bar $=10 \mu \mathrm{m}$ 
Table 1. Comparison of the key characters of genera of the Catathelasmataceae recognized in this study and the genus Cleistocybe.

\begin{tabular}{|c|c|c|c|c|c|c|c|}
\hline & Callistosporium & Catathelasma & Macrocybe & Pseudolaccaria & Pleurocollybia & Guyanagarika & Cleistocybe \\
\hline Stature type & Collybioid & $\begin{array}{l}\text { Tricholomatoid, } \\
\text { veil-double }\end{array}$ & Tricholomatoid & Tricholomatoid & $\begin{array}{l}\text { Pleurotoid, } \\
\text { collybioid }\end{array}$ & Tricholomatoid & $\begin{array}{l}\text { Clitocyboid, with } \\
\text { veil }\end{array}$ \\
\hline Lamellae & $\begin{array}{l}\text { Subdecurrent, } \\
\text { adnexed or } \\
\text { emarginated }\end{array}$ & $\begin{array}{l}\text { Decurrent or } \\
\text { adnate to sinuate- } \\
\text { adnexed }\end{array}$ & Attached & Emarginate & $\begin{array}{l}\text { Adnexed, sinuate, } \\
\text { adnate or slightly } \\
\text { decurrent }\end{array}$ & $\begin{array}{l}\text { Adnexed to sub- } \\
\text { sinuate }\end{array}$ & $\begin{array}{l}\text { Decurrent to long } \\
\text { decurrent }\end{array}$ \\
\hline $\begin{array}{l}\text { Hymenophoral } \\
\text { trama }\end{array}$ & Regular & $\begin{array}{l}\text { Bilateral } \\
\text { becoming regular }\end{array}$ & Regular & Regular & Regular & Regular & $\begin{array}{l}\text { Interwoven to } \\
\text { subparallel, more } \\
\text { or less divergent } \\
\text { when young }\end{array}$ \\
\hline Basidiospores & $\begin{array}{l}\text { Ellipsoid, smooth, } \\
\text { inamyloid, } \\
\text { scarcely or weakly } \\
\text { cyanophilic }\end{array}$ & $\begin{array}{l}\text { Oblong, amyloid, } \\
\text { smooth, } \\
\text { acyanophilic }\end{array}$ & $\begin{array}{l}\text { Ellipsoid, smooth, } \\
\text { inamyloid, } \\
\text { cyanophilic }\end{array}$ & $\begin{array}{l}\text { Ellipsoid, smooth, } \\
\text { amyloid, } \\
\text { cyanophilic }\end{array}$ & $\begin{array}{l}\text { Ellipsoid, smooth, } \\
\text { inamyloid, weakly } \\
\text { to distinctive } \\
\text { cyanophilic }\end{array}$ & $\begin{array}{l}\text { Ellipsoid, smooth, } \\
\text { inamyloid, with } \\
\text { guttules, } \\
\text { acyanophilic }\end{array}$ & $\begin{array}{l}\text { Ellipsoid to } \\
\text { oblong to ovate or } \\
\text { subfusoid, } \\
\text { smooth, } \\
\text { inamyloid, } \\
\text { acyanophilic } \\
\end{array}$ \\
\hline Cheilocystidia & None & Cylindrical & None & None & $\begin{array}{l}\text { Sometimes } \\
\text { present }\end{array}$ & None & None \\
\hline Pleurocystidia & None & None & Pseudocystidia & None & None & None & None \\
\hline Clamps & Absent & Present & Present & Present & Absent & Present & Present \\
\hline Pileipellis & $\begin{array}{l}\text { Cutis; hyphae } \\
\text { with encrusting } \\
\text { and intracellular } \\
\text { pigments }\end{array}$ & Ixocutis & Cutis & $\begin{array}{l}\text { Cutis of encrusted } \\
\text { hyphae }\end{array}$ & $\begin{array}{l}\text { Cutis-like, } \\
\text { filamentous } \\
\text { hyphae } \\
\text { multiseptate }\end{array}$ & $\begin{array}{l}\text { Cutis becoming a } \\
\text { trichoderm; } \\
\text { hyphae with } \\
\text { intracellular } \\
\text { pigments }\end{array}$ & $\begin{array}{l}\text { Interwoven, non- } \\
\text { gelatinous or } \\
\text { gelatinous }\end{array}$ \\
\hline Habitat & $\begin{array}{l}\text { On the base of } \\
\text { palm trees, wood, } \\
\text { Sphagnum, earth }\end{array}$ & $\begin{array}{l}\text { Terrestrial under } \\
\text { conifers }\end{array}$ & $\begin{array}{l}\text { On soil, } \\
\text { grasslands, sand, } \\
\text { ant nests }\end{array}$ & $\begin{array}{l}\text { Sandy soil, } \\
\text { coniferous forests, } \\
\text { grasslands }\end{array}$ & On rotten wood & $\begin{array}{l}\text { On soil under } \\
\text { tropical } \\
\text { hardwoods }\end{array}$ & Terrestrial \\
\hline Nutritional habit & Saprotrophic & Ectomycorrhizal & Saprotrophic & Saprotrophic & Saprotrophic & Ectomycorrhizal & Saprotrophic \\
\hline Distribution & $\begin{array}{l}\text { Asian tropics, } \\
\text { America, Canada } \\
\text { to Argentina, } \\
\text { Europe }\end{array}$ & $\begin{array}{l}\text { Europe, North } \\
\text { America, Japan }\end{array}$ & Tropics & Europe & $\begin{array}{l}\text { Temperate and } \\
\text { Tropical Americas }\end{array}$ & $\begin{array}{l}\text { Neotropics } \\
\text { (Guyana) }\end{array}$ & North America \\
\hline
\end{tabular}




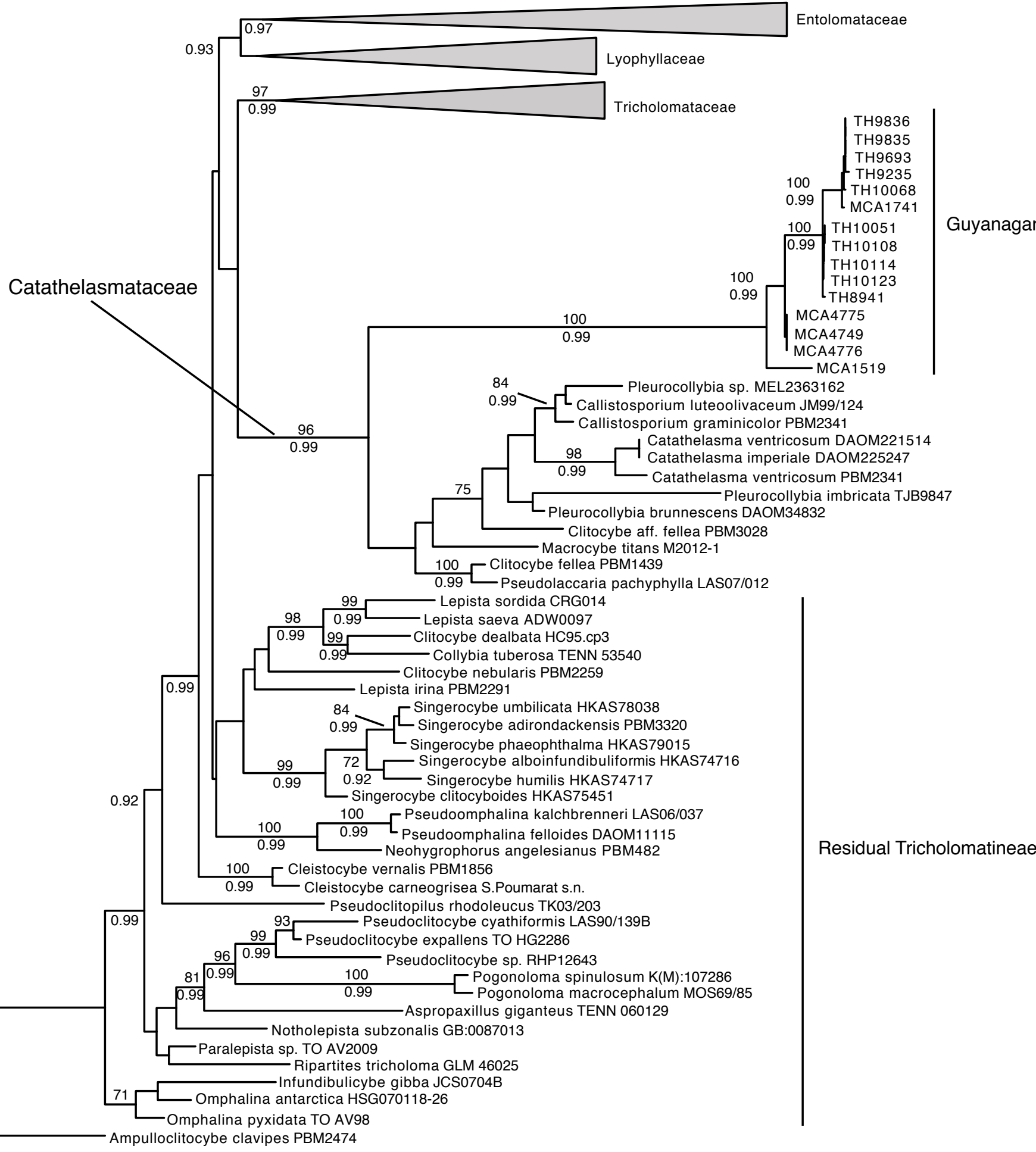




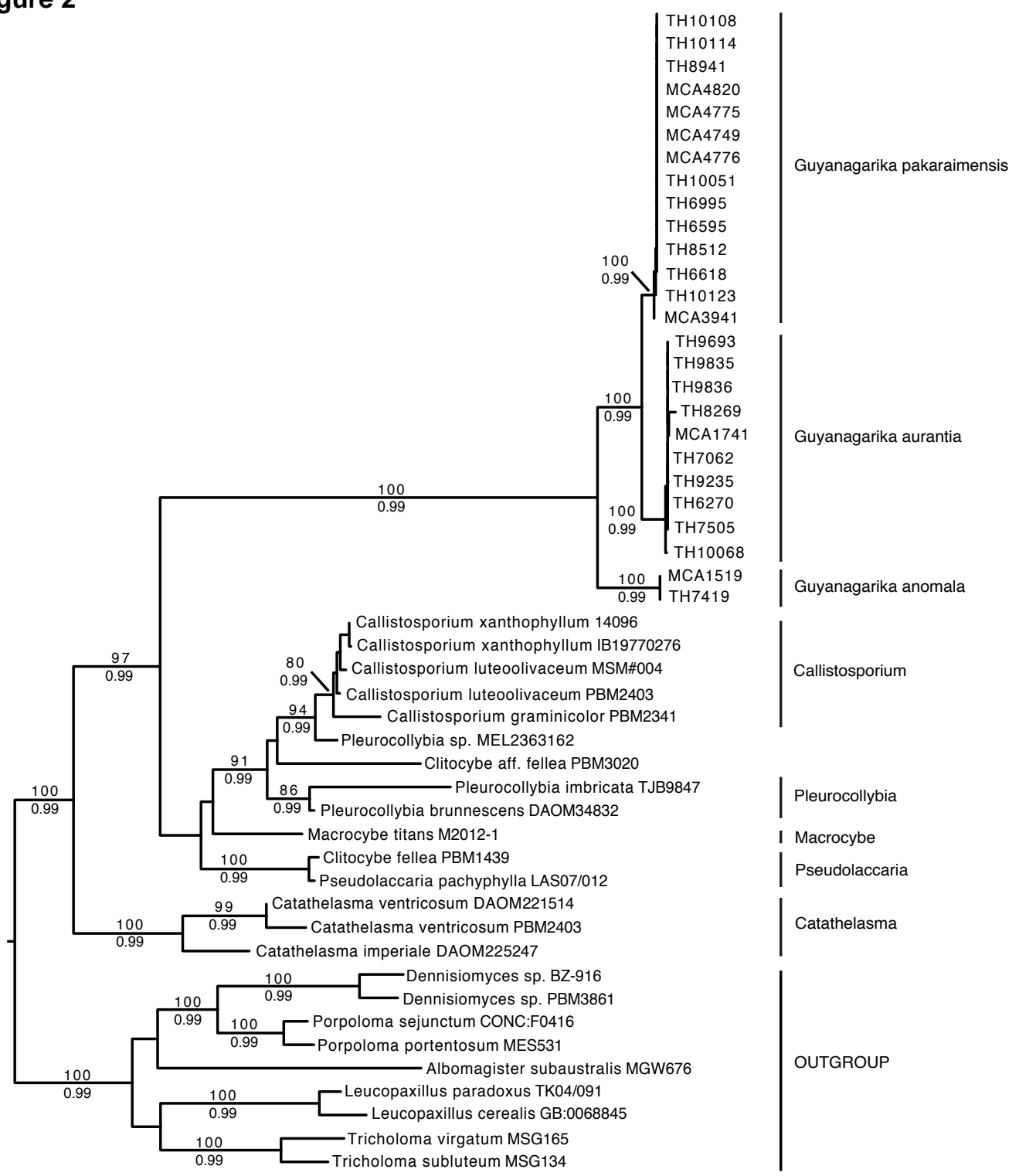



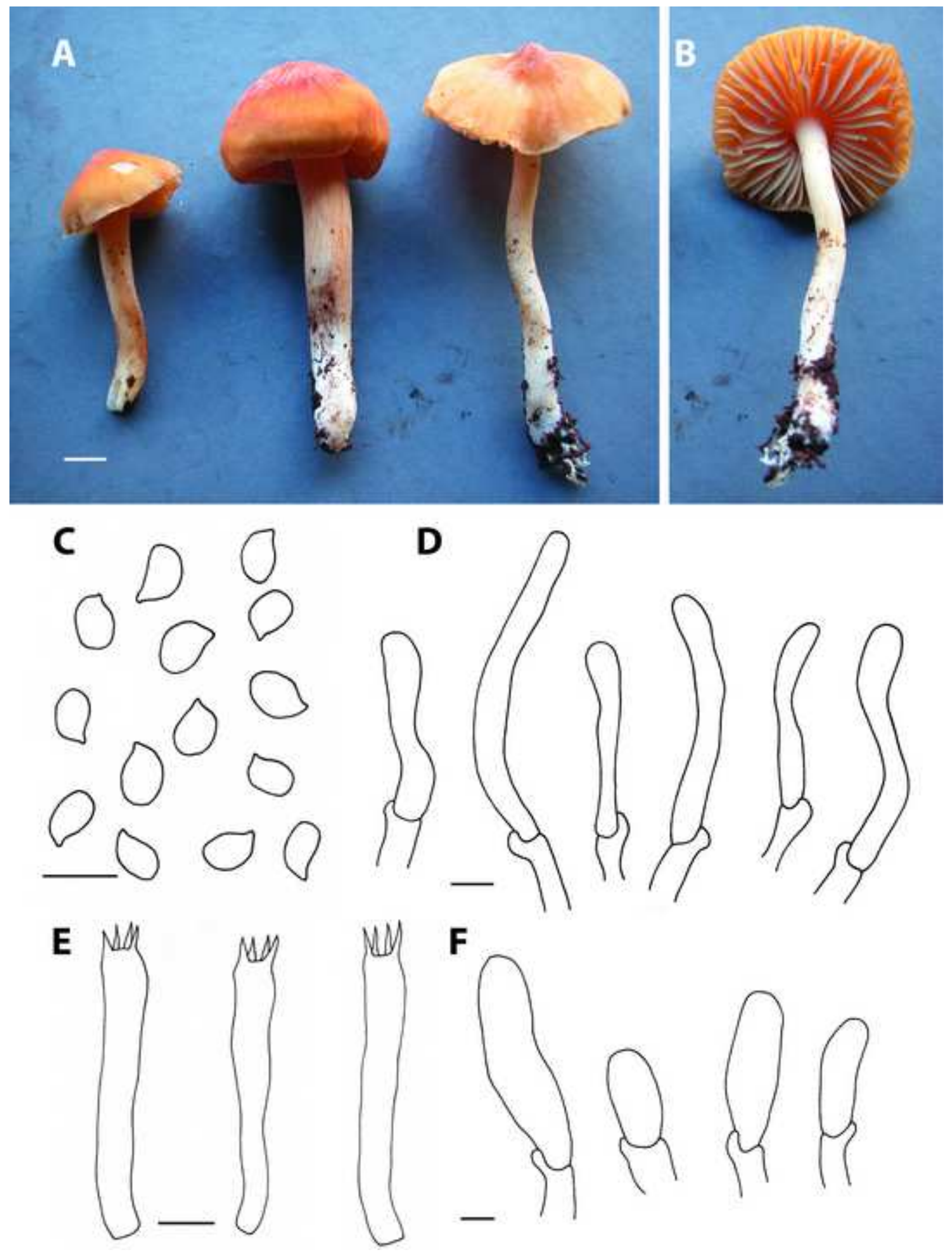

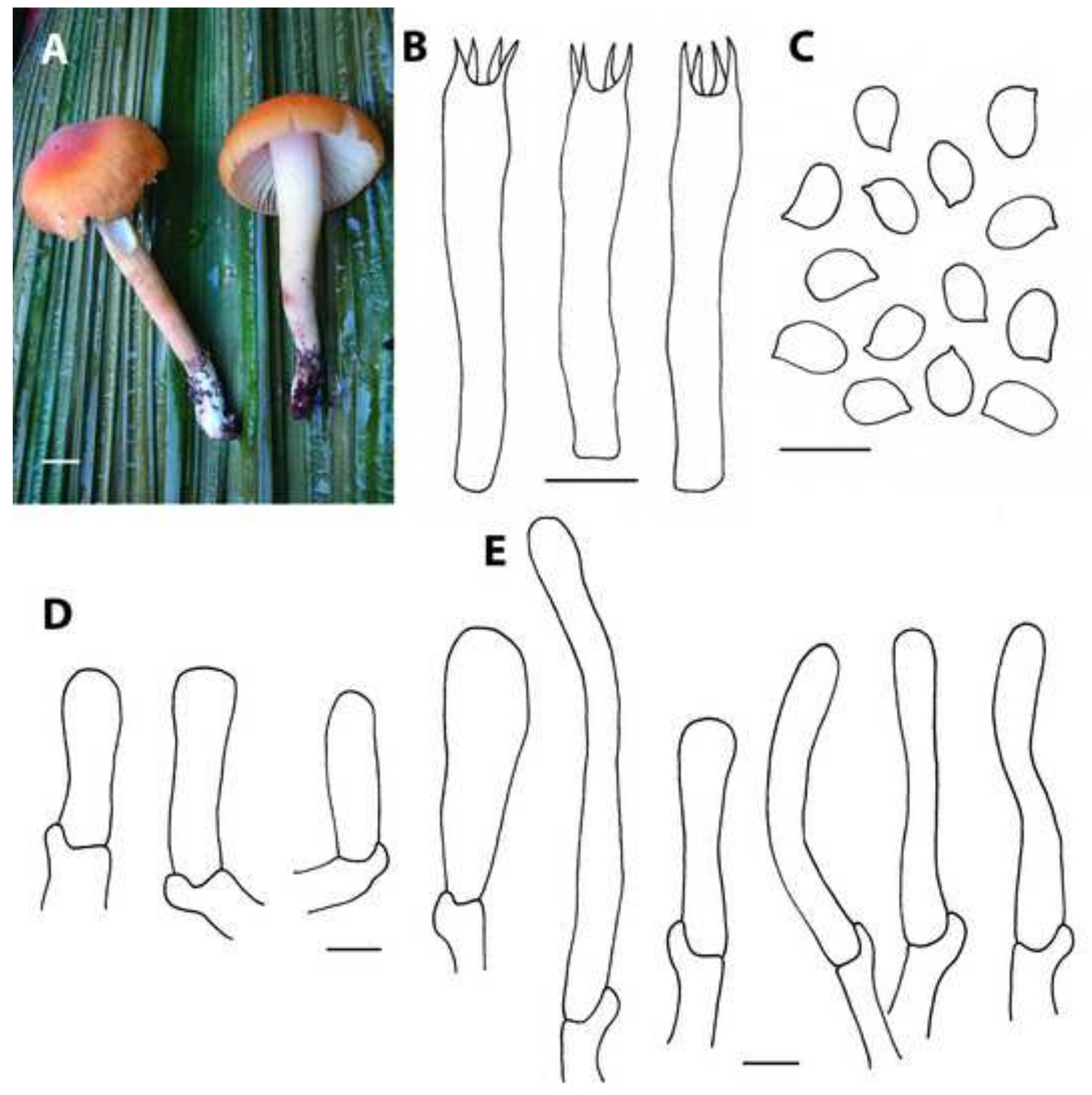
Figure 5
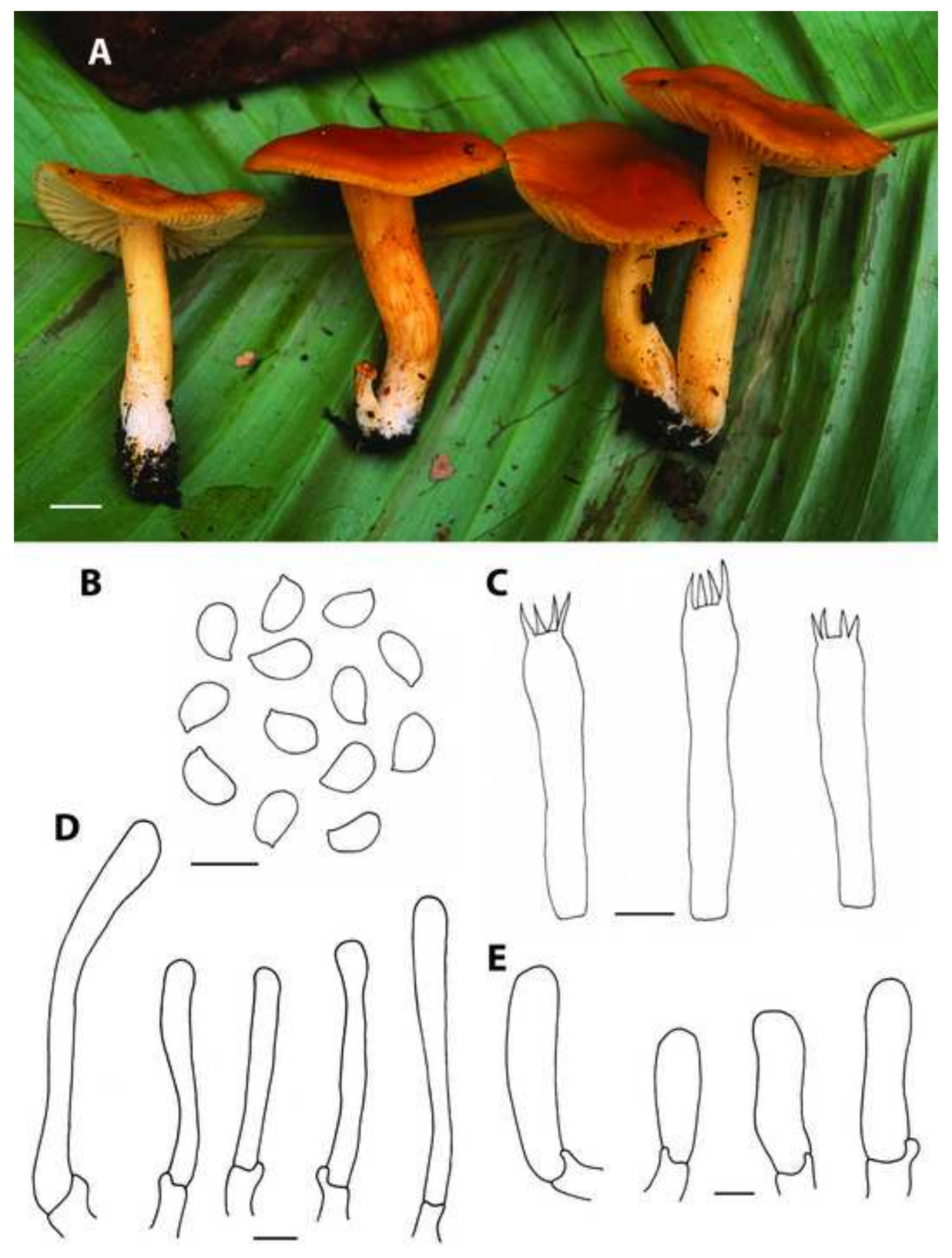

.

5
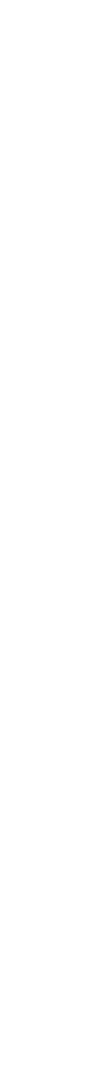